\title{
Got the picture? Image, image schemata, imaginative reason
}

Jean-Rémi Lapaire

\section{(2) OpenEdition \\ Journals}

Electronic version

URL: http://journals.openedition.org/asp/1998

DOI: 10.4000/asp.1998

ISBN: 978-2-8218-0382-4

ISSN: 2108-6354

Publisher

Groupe d'étude et de recherche en anglais de spécialité

\section{Printed version}

Date of publication: 31 December 2000

Number of pages: $7-17$

ISSN: 1246-8185

\section{Electronic reference}

Jean-Rémi Lapaire, "Got the picture? Image, image schemata, imaginative reason », ASp [Online], 27-30 | 2000, Online since 27 December 2010, connection on 19 April 2019. URL : http:// journals.openedition.org/asp/1998; DOI : 10.4000/asp.1998

This text was automatically generated on 19 April 2019.

Tous droits réservés 


\title{
Got the picture? Image, image schemata, imaginative reason
}

\author{
Jean-Rémi Lapaire
}

1 Eight $^{1}$ weeks after the successful launch of the Euro - the common European currency Tony Blair pledged that he would speed up the process of monetary union. In the editor's own words, this amounted to "prodding the British a little more quickly up the monetary aisle."

Figure 1. "Nearer to the altar" in The Economist Feb 27th - March 5th 1999

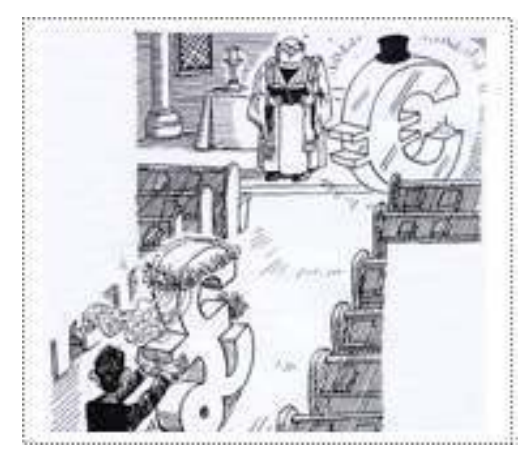

2 The standard dictionary definition of a cartoon is "a humorous drawing dealing in a clever and amusing way with something of interest in the news."

3 As all readers of newspapers and magazines know, the best cartoons are those that blend visual and verbal language to expose some crucial moral, social or political truth. Success largely depends on the cartoonist's ability to create a conceptually accurate, thoughtprovoking and entertaining situation. But how does one 'provoke' thought using the limited resources of a highly simplified and conventionalized pictographic vocabulary? How can one "entertain" the bored, skeptical or merely indifferent reader with a minor episode in the dull financial saga of European monetary integration? How can a thoroughly unrealistic scene capture the essence of reality? How come we make so much sense of such pictorial nonsense? 
Cognitive semantics may have some answers.

4 As a relatively new discipline in the emergent field of cognitive science, cognitive semantics studies the way we categorize, conceptualize and reason. It identifies knowledge structures and explores common modes of understanding. In Mark Johnson's words,

It is a program of empirical research in linguistics, psychology, philosophy, and the other cognitive sciences that stresses the embodied and imaginative character of human cognition. (1993: 265-66).

5 To a cognitive linguist, cartoons are certainly among the most powerful revealers of human conceptual structures and projections. Nowhere else is "the imaginative structure of human understanding" (Johnson 1993) more apparent. Nowhere else is the organization of knowledge into shared sociocultural frames more visible. Nowhere else are the central cognitive mechanisms known as mapping and blending more accessible.

\section{Conceptual "connections", "projections" and "blends"}

\subsection{Mapping}

6 A connection is set up between two distinct domains:

1. the conventional Christian wedding ceremony [which constitutes 'the source domain']

2. European monetary integration ['the target domain']

7 As in any cartoon, the connection is both visual and conceptual. The reader is expected to engage in 'visual thinking' (Arnheim 1969) - an experience which fuses image and concept, perception and intellection.

8 We look and think at the same time; processing visual data and negotiating meaning simultaneously. In this particular cartoon, image processing and meaning construal require projecting shared cultural knowledge about marriage onto monetary union. This is called a 'source-to-target mapping', where 'marriage' acts as the 'source' or 'trigger' and monetary union as the 'target'.

Figure 2. Mapping

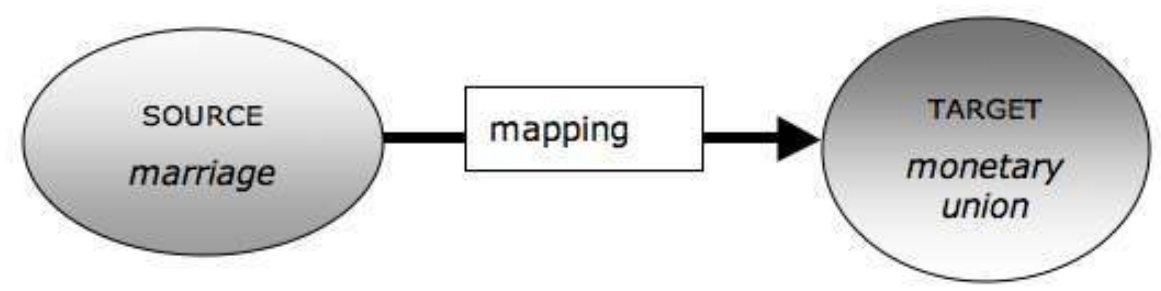

9 Mapping is a cognitive process which transfers both 'form' and 'substance', i.e., the semiotic coding and its associated conceptual structure.

10 Several key notions need to be defined before pursuing the discussion:

a. "projection" requires activation: the projected conceptual structure (e.g., our knowledge of marriage as a cultural institution and a codified social performance) becomes a dynamic processing medium. It no longer lies dormant, as a static mental configuration. Our 
understanding of the political statement made by the cartoon requires that pre-structured knowledge pertaining to "holy matrimony" should become cognitively active.

b. a wedding ceremony is a ritual which follows a particular script. It has far-reaching social, moral and legal consequences for the bride and the groom. It is part of a well-established cognitive frame (cf. the ${ }_{\text {wedding }}$ entry in Longman Dictionary of English Language and Culture 1998: 804).

c. some typical aspects of the standard wedding script have been left out. We see no mothers, no brothers, no sisters, no friends, no flower girls, no pageboy! This is by no means unusual. In most -if not all- source-to-target mappings, only part of the source domain is activated to conceptualize the target domain.

d. additional characters and props could be called into the picture if the metaphor were to be elaborated further. Currencies from Commonwealth countries - like the Australian Dollarmight act as caring friends taking pictures during the ceremony or preparing confetti and rice. Later, bride and groom might be seen travelling as backpackers on a crowded Eurobus; the honeymoon trip being slightly rougher than expected. Alternatively, we might have caught a glimpse of the disastrous wedding night and failed "dream vacation" in Bora Bora: the Euro plays golf with his business partners - the arrogant Yen and the fat American Dollar - while the disillusioned and homesick Pound calls up her relatives and sobs嘼

e. the mapping is used to highlight meaningful (or relevant) aspects of monetary union. The message here is "This may look like a happy occasion, but beware! The moment 'she' marries the Euro, the pound will lose her maiden name and forsake her independence."

11 Other stories might have sent a different message, simply because the visual conceptualization of the event would have been achieved via a different metaphorical mapping. Tony Blair might have been featured as a baker adding "Sterling topping" to a gigantic "European Currency cake." Among possible developments, a threatening US dollar might have been shown lurking in the background, ready to devour the tasty, creamy, Sterling-topped Eurocake.

Countless tales could be invented, using the boundless resources of imaginative reason:

We human beings are imaginative creatures, from our most mundane, automatic acts of perception all the way up to our more abstract conceptualization and reasoning. (Johnson 1993, 1997: ix)

\subsection{Blending}

13 Source-to-target mappings offer a useful, manageable yet incomplete representation of conceptual transfers. The simple, direct, one-way projection of knowledge described in 1.1. could be regarded as a simplified account of a more complex mental mechanism involving a minimum of two input spaces and two middle spaces (Fauconnier \& Turner 1994): 


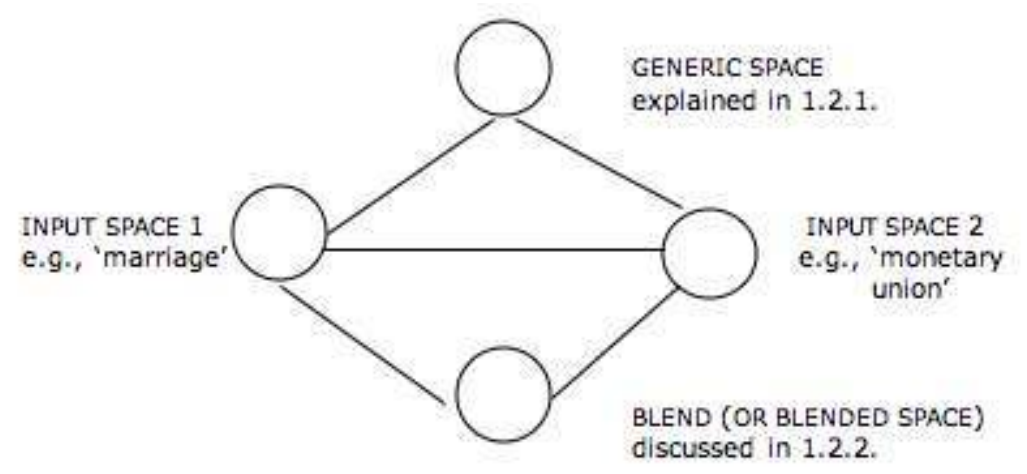
conceptual domains. In Fauconnier and Turner's model, mental spaces are the particular knowledge structures set up to achieve a particular conceptual projection. Although their internal configuration borrows structure from general conceptual domains (e.g., "holy matrimony"; "monetary integration") they also inherit structure from the situational context (e.g., Tony Blair's personal record on a common European monetary policy; the reluctance of the British electorate to relinquish more sovereignty to a handful of Frankfurt-based Eurobankers, etc.).

(Fauconnier 1994: 4). As shown on the diagram, they are interconnected and interdependent. Each space makes a contribution to the overall conceptual structure. Hence the replacement of source and target domain by input 1 and input 2 .

The "generic space" and the "blended space" are "middle spaces". The first motivates the conceptual connection between the "input spaces", while the second allows the creation of a new, imaginary setting.

\subsubsection{The GENERIC SPACE}

17 The connection between the input spaces is never random. Some amount of structure must be common to both domains. This is known as the "principle of access" (Sweetser \& Fauconnier 1996).

[...] an expression which names or describes one entity (the trigger) can be used to access (and hence refer to) an entity in another domain (the target) only if the second domain is cognitively accessible from the first, and if there is a connection between trigger and target. (Fauconnier 1994: 7) [emphasis added]

The "generic space" covers the area of conceptual overlap, structural similarities and shared sociophysical properties between the two input spaces:

The generic space reflects some common, usually more abstract, structure and organization shared by the inputs and defines the core cross-mapping between them. (Fauconnier 1997: 149)

Holy matrimony [= input space 1] is used to "access" monetary integration [= input space 2] by virtue of its shared roles, frames and schemas:

- the ${ }_{\text {link }}$ schema (Johnson 1987). Two distinct entities are joined together, as reflected in common linguistic usage: the bride and groom are united in holy matrimony [input 1]; joining the Euro zone is part of the process of monetary union [input 2]. 
- the union is a formal agreement: documents are signed which are legally binding to both parties. Marriage [input 1] and monetary union [input 2] are strictly codified transactions.

- preliminary negotiations are needed. This is usually performed in private but the final agreement is public.

- powerful male figures traditionally control the event: the bride's father [holy matrimony]; the prime minister or the Chancellor of the Exchequer [monetary union].

- the bride and the pound are in focus during the ceremony. But as soon as the legal documents are signed, they will (a) lose control of their own destiny (b) recede into the background.

\subsubsection{The BLENDED SPACE}

As Fauconnier remarks "Humor makes abundant use of blends" (1997: 185). "Nearer to the Altar' does more than support this statement: it provides a perfect example of visual blending.

Technically, blending is a "merging operation" which "combines specifics from source and target, yielding an impression of richer, and often counterfactual or 'impossible' structure" (Fauconnier \& Turner 1994: 5).

22 In 'Nearer to the Altar', the pound is featured as a shy bride and the Euro poses as an independent, slightly arrogant bridegroom. Social life and financial mechanisms are visually merged. The scene is totally unrealistic but its 'impossible' nature does not prevent it from being visually explicit. Strange as it may seem, it is the very imaginary (Johnson) or 'counterfactual' (Fauconnier) nature of the visual blend that enhances its conceptual clarity.

Blending obeys a set of consistent rules listed in Fauconnier 1997 (150-54). Three of these deserve special mention here:

\section{1. "The blend remains hooked up to the inputs."}

4 To make sense of the visual blend created by the cartoonist, mental contact must be kept with the two spaces associated with 'holy matrimony' and 'monetary union'. The reader has a foot in both spaces and must adjust visually and conceptually to the available 'background structures and inferences' of the two domains.

2. "The blend has emergent structure not provided by the inputs. [T] he projections from the inputs make new relations available that did not exist in the separate inputs."

In the typical wedding ceremony [input space 1] the father does not push his daughter up the aisle to speed up the ceremony. But in the financial process of monetary union [input space 2], the Prime Minister may indeed push reform and speed up the integration of the Pound into the Euro zone.

It is important to note that the blend inherits its causal and intentional structures from input 2, but visually translates it in terms of input 1 .

Input 1 provides the concrete structure of church, altar, priest, ring, etc., and this is exactly what makes the cartoon so amusing. The conventional expectations associated with the wedding script are not fulfilled: we expect to see a slow-paced and dignified father but find a somewhat panicked, dishevelled-looking man who seems to be in a terrible rush to marry his daughter. 
3. "The structure in the blend can be elaborated. This is 'running the blend'. It consists in cognitive work performed within the blend, according to its own emergent logic." "mouse" and "clicking" - have little to do with the real motor actions found in ordinary writing, erasing, carbon-copying, etc. The blended space of the Macintosh or Windows 2000 interface is a world governed by its own rules. It has its "emergent structure". As computer users, we "run the blend" every day. We normally do this with a fair amount of success. But sometimes, there are cruel reminders of the cognitive gap separating the traditional desktop from the modern computer station. When we use a pen, we do not need to "save" what we have just written. Marks are marks and normally stay where they are (for some time at least!). Erasing is a conscious and voluntary act. But this is not so when we use a word-processor. On exiting a file, we normally get a message asking us to confirm that we really want to "save" the work that we have done. If we overlook the instruction or click in the wrong place, we may discover to our cost that words on a computer screen are ethereal, self-deleting creatures.

All things considered, the modern, mercantile concept of "user-friendliness" means little else than cognitively accessible.

\section{Narration as a conceptualizing device}

There is a universal tendency to make sense of human action by applying narrative structure to real world events. Lawyers and lexicographers may conceive of marriage as 'the legal union made by a man and a woman to live as husband and wife'. But to most of us, marriage is one of life's many stories.

Marriage is commonly conceptualized in terms of a boy meets girl story with plot, character and role assignment. So is monetary union, which may be construed as a pound meets Euro story, with Tony Blair cast as the bride's father in the conventional marriage 
script. Other plots could be used to frame the same reality. The more primitive genre of the epic would be particularly appropriate here, with the Prime Minister engaging in a heroic battle against the evil Eurosceptics.

That harsh, unromantic financial processes should assume story form is hardly surprising. Many subjects, including the most technical ones - virus infections, nuclear fission, computer programmin... - resort to narrative as a conceptualizing device. It is no coincidence that Christ spoke in parables to conceptualize moral truths. It is no coincidence either that Freud imported Greek myths - in particular the Oedipus story not only to describe but to conceptualize neurosis. Interestingly, his case studies are narratives which dramatize emotional and representational processes.

In Mark Johnson's words, “we are narrative creatures” (1997: 180). Not only do we give narrative accounts of ourselves, but we are for ever engaged in the narrative construction of meaning. One reason for doing this, is that narrative gives structure and cohesion to what would otherwise seem discrete, or isolated events and concepts (as clearly demonstrated by Paul Ricoeur in Time and Narrative). More fundamentally, narrative is rooted in the SOURCE-PATH-GOAL image schema, which is central to our bodily interaction with the world and accordingly to most of our conceptualizations.

One last point deserves to be made here. Cartoons are static pictures that have their own internal structure and allow the representation of simultaneous interaction in space. One look is enough to catch a synthetic view of a complex scene. But as soon as we start describing what we see, the syntax of verbal language forces us to fragment the visual whole into discrete elements and place them in linear sequence. The conversion of visual into verbal data turns description into narration: 'The church is almost empty. The priest and the bridegroom stand waiting for the bride...'.

\section{Image schemata}

We need and want to rebuild the bridge between perception and thinking. (Arnheim 1969: 153)

Concept-formation, perception and interaction cannot be separated. Image schemata are "structures for organizing our experience and comprehension" (Johnson 1987: 29). They derive from primary sensorimotor experience and act as preconceptual structures. For example, we use the CONTAINER schema to form the more elaborate concept of category (e.g., IN a group, INSIDE a party).

[...] human bodily movement, manipulation of objects, and perceptual interactions involve recurring patterns without which our experience would be chaotic and incomprehensible. I call these patterns 'image schemata', because they function primarily as abstract structures of images. (Johnson 1987: xix)

Image schemata include visual schemata as well as other perceptual and interactional modalities. Their existence remains to be established on a neurophysical basis. If this happens, then proof will be given that motor programs play a central role in shaping knowledge structure.

Image schemata have gestalt structure. However basic and simple they may seem, they function as totalities made up of interrelated parts.

41 Image schemata are grounded in primary experience. They are abstractions formed on the basis of our sociophysical interaction with the world. 
[...] human concepts are not just reflections of an external reality, but are crucially shaped by our bodies and brains, especially by our sensorimotor systems. (Lakoff \& Johnson 1999: 22)

Image schemata are not "images" in the full sense:

[...] image schemata are not rich, concrete images or mental pictures. They are structures that organize our mental representations at a level more general and abstract that at which we form particular mental images. (Johnson 1987: 24)

'Nearer to the altar' provides a vivid illustration of three central image schemata.

\subsection{The SOURCE-PATH-GOAL \& FROM-TO image schema}

(as described in Johnson 1987: 28-29)

Gestalt structure: a source point A, a terminal point B, a vector tracing a path + motion along the path (forced, voluntary, self-propelled) + directionality

Primary experience (grounding):

This FROM-TO schema is a recurrent structure manifested in a number of seemingly different events, such as: (a) walking from one place to another, (b) throwing a baseball to your sister; (c) punching your brother, (d) giving your mother a present, (e) the melting of ice into water. (Johnson 1987: 28)

This image schema provides a general frame for political action: Britain, metonymically represented by Tony Blair and the bride ( $€$ ), is moving towards monetary union. The Prime Minister wants to proceed or go ahead with reform. He is now pushing things. A change of state is (typically) construed as a change of location. The transition from the old to the new monetary order is understood as a short but decisive journey along a path (i.e. the aisle). Such is the course of events...

\subsection{The FORCE Schema}

(Johnson 1987: 44-48)

Gestalt structure and socio-physical grounding: compulsion (being moved by an external force like the wind, a crowd, etc.); blockage (barriers that block or resist our force); counter-force ; removal of restraint; attraction, etc.

This is a schema which is routinely applied to conceptualize authority. French has a number of phrases expressing compulsion in terms of physical forces: "pousser à", "forcer à". English uses similar expressions: "forced to...", "driven to..." (cf. Leonard Talmy's and Eve Sweetser's accounts of the English modals in terms of force dynamics). In 'Nearer to the altar', the Prime Minister shows his power and influence by literally pushing the bride in the back, up "the monetary aisle".

\subsection{The LINK schema}

(Johnson 1987: 116-117)

Gestalt structure and sociophysical grounding: two distinct entities and a connection between them.

Social relationships like friendships, marriage, diplomacy, etc. are fundamentally structured by the link schema (e.g., 'the bonds of friendship', 'diplomatic ties'). Marriage, just like monetary union, is a link [as discussed in 1.2.1.] 


\section{Conclusion} 1997: 189) that involve preconstructed knowledge structures (e.g., cognitive domains or frames, scripts, image schemata) and mental operations (e.g., cross domain mappings or blends). Since most cognitive processes operate below the level of consciousness, we may wonder how mappings, blendings and, more generally, conceptual projections are carried out by the brain.

But this may not be so important after all. The latest advances made in Functional Magnetic Resonance Imaging (FMRI) - a device which captures the brain in action as it engages in a cognitive task ${ }^{2}$ - have opened more windows to the mind. Yet, in the foreseeable future, language is likely to remain what it has always been: the most readily accessible source of insight into the deep cognitive processes governing the sociophysical construction of meaning.

\section{BIBLIOGRAPHY}

Arnheim, Rudolph. 1969. Visual Thinking. Berkeley, CA: University of California Press.

Edelman, Gerald. 1992. Bright Air, Brilliant Fire. London: Penguin.

Fauconnier, Gilles. 1984. Espaces mentaux. Paris: Les Éditions de Minuit.

Fauconnier, Gilles. 1997. Mappings in Thought and Language. New York: Cambridge University Press.

Fauconnier, Gilles and Eve Sweetser. 1996. Spaces, Worlds and Grammar. Chicago, IL: University of Chicago Press.

Fauconnier, Gilles and Mark Turner. 1994. “Conceptual Projection and Middle Spaces”. Report 9401. San Diego: Department of Cognitive Science, University of California.

Johnson, Mark. 1987. The Body in the Mind. The Bodily Basis of Meaning, Imagination, and Reason. Chicago, IL: University of Chicago Press, 1987.

Johnson, Mark. 1993. Moral Imagination. Chicago, IL: University of Chicago Press.

Lakoff, George and Mark Johnson. 1980. Metaphors We Live By. Chicago, IL: University of Chicago Press.

Lakoff, George and Mark Johnson. 1999. Philosophy in the Flesh. New York: Basic Books.

Sweetser, Eve. 1990. From Etymology to Pragmatics. Metaphorical and Cultural Aspects of Semantic Structure. Cambridge: Cambridge University Press.

Talmy, Leonard. 1985. "Force Dynamics in Language and Thought". Papers from the Parasession on Causatives and Agentivity. Chicago, IL: Chicago Linguistic Society.

Talmy, Leonard. 2000. Toward a Cognitive Semantics. Cambridge, MA: MIT Press. 


\section{NOTES}

1. This paper was presented as a plenary lecture at the GERAS conference in Dijon, March 2000.

2. An area that is activated lights up because of the increased blood flow. FMRI thus allows researchers to peer inside the thinking and feeling human brain. Knowing where something happens, however, does not say much about how it happens.

\section{ABSTRACTS}

This is an introduction to the field of cognitive semantics, using the visual data provided by a single cartoon ("Nearer to the altar") and some of the analytical tools devised by George Lakoff, Mark Johnson, Mark Turner, Eve Sweetser and Gilles Fauconnier. Special emphasis is placed on the conceptual projections that allow us to reason and construct meaning. The presentation includes a detailed discussion of blending in mental space theory and explores the imaginative and narrative character of human knowledge.

La sémantique cognitive pratiquée par George Lakoff, Mark Johnson, Mark Turner, Eve Sweetser et Gilles Fauconnier propose un certain nombre d'outils pour rendre compte des mécanismes psychiques par lesquels le sens se construit. À partir du support visuel fourni par un dessin humoristique ( Nearer to the altar»), nous nous attachons à définir les notions de transfert conceptuel et d'espace mental. Une attention particulière est accordée au phénomène de blending (imbrication/superposition de deux espaces distincts) ainsi qu'à la structure imaginaire et narrative du savoir humain.

\section{INDEX}

Mots-clés: espace mental, imagination, narration, raison, schème, sémantique cognitive, transfert conceptuel

Keywords: cognitive semantics, image schema, imaginative reason, mapping, mental space, narration, visual blend

\section{AUTHOR}

\section{JEAN-RÉMI LAPAIRE}

Jean-Rémi Lapaire est professeur à l'Université de Toulouse-Le Mirail. Fondateur d'un atelier de recherche en linguistique cognitive (Cognilingua), il travaille actuellement à la jonction entre les théories de l'énonciation, dominantes en France, et les approches cognitives développées en Californie. Il est par ailleurs impliqué dans un vaste projet de didactisation des approches cognitives de la grammaire chez Hachette Éducation. L'utilisation de structures narratives, le 
recours à l'imaginaire et l'intégration du corps au processus explicatif sont des traits originaux de la méthode qu'il est en train d'élaborer. Jean-Remi.Lapaire@u-bordeaux3.fr 